\title{
Use of RAPD-PCR for genetic analyses on the native cattle breeds in Turkey"
}

\author{
Güven GÜNEREN ${ }^{1}$, Bilal AKYÜZ ${ }^{2}$, Okan ERTUGRUL ${ }^{3}$ \\ ${ }^{1}$ SSA Consultant for the World Bank and European Commission; ${ }^{2}$ Erciyes University, Faculty of Veterinary Medicine, Department \\ of Animal Science; ${ }^{3}$ Ankara University, Faculty of Veterinary Medicine, Department of Genetics.
}

\begin{abstract}
Summary: The purpose of this study was to identify the genetic relationship and variations within and between local cattle breeds of Turkey using RAPD-PCR method which needs fewer substructures when compared to other DNA fingerprinting methods. The RAPD-PCR method was performed on blood samples of 77 animals from four breeds namely Anatolian Black (AB), East Anatolian Red (EAR), South Anatolian Red (SAR) and Turkish Grey Steppe (TG). A set of ten arbitrary 10-mer primers were used to detect the DNA polymorphisms in the whole genome. Estimation of the genetic distances between the breeds was conducted through the $\mathrm{F}_{\mathrm{ST}}$ Distant Estimation Method, and cluster trees were constructed by UPGMA Method. Based on the band sharing method, the average genetic variances of the breeds varied from 0.637 (in TG) to 0.809 (in SAR), AB and EAR had 0.792 and 0.787 , respectively. It was concluded that $\mathrm{AB}$ breed is more closely related to EAR breed than to SAR breed while TG breed was determined as a distinct group from other breeds.
\end{abstract}

Key words: Breed characterization, native cattle breeds of Turkey, DNA fingerprinting, phylogeny, RAPD-PCR.

\section{Türkiye’deki yerli sığır ırklarında genetik analiz için RAPD-PCR kullanımı}

Özet: Bu çalışmada, diğer DNA parmak izi yöntemleri ile karşılaştırıldığında daha az alt yapıya ihtiyaç duyan RAPD-PCR metodu kullanılarak Türkiye yerli sığır ırklarında ırk içi ve ırklar arası genetik ilişki ve genetik varyasyonların belirlenmesi amaçlanmıştır. RAPD-PCR metodu Yerli Kara (YK), Doğu Anadolu Kırmızısı (DAK), Güney Anadolu Kırmızısı (GAK) ve Boz Irk'tan (BI) toplam 77 hayvandan alınan kan örnekleri kullanılarak yapılmıştır. DNA'larda polimorfizmleri belirlemek için 10 bazdan oluşan 10 primer seti kullanılmıştır. Irklar arası mesafe $\mathrm{F}_{\mathrm{ST}}$ Mesafe Tahmin Metoduyla, ırklara ait gruplama ağaçları UPGMA metoduyla yapılmıştır. Bantların varlığına göre ırkların ortalama genetik varyansları 0,637 (BI)'den 0,809 (GAK)'a kadar değiştiği görülmüştür. YK ırkının DAK ırkına GAK ırkından daha yakın olduğu, BI ise her üç ırktan farklı bir kümede bulunduğu belirlenmiştir.

Anahtar sözcükler: DNA parmak izi, filogenetik, ırk karakterizasyonu, Türkiye yerli sığır ırkları, RAPD-PCR.

\section{Introduction}

Extinction of any local breed or population may result in the complete loss of some valuable alleles. Turkish native cattle breeds are among the endangered breeds in Turkey. Based on phenotypic traits, four indigenous cattle breeds are though to exist in Turkey, namely the Anatolian Black (AB), East Anatolian Red (EAR), South Anatolian Red (SAR) and Turkish Grey Steppe (TG). To date, there are a few studies on blood protein polymorphisms in native Turkish cattle breeds $(10,15)$.

The ability to detect polymorphisms at the DNA level has led to new approaches for the genetic analysis of farm animals. Furthermore, an understanding of the pattern of genetic variability among breeds may help in the development of more rational breeding programs (9). Genetic markers are powerful tools to investigate the phylogenic relationships and differentiation among breeds $(2,3,9,12)$. Various molecular markers have been identified in livestock species, such as protein polymorphism, randomly amplified polymorphic DNA (RAPD), restriction fragment length polymorphism (RFLP), amplified fragment length polymorphism (AFLP), variable number tandem repeat (VNTR), single nucleotide polymorphism (SNP), short tandem repeat (STR) and microsatellite polymorphisms $(2,9,24)$.

The RAPD technique was developed by Williams et al. $(12,24)$. The technique is based on polymerase chain

\footnotetext{
* Bu çalışma "Polimeraz Zincir Reaksiyonu ile Rasgele Çoğaltılmış Polimorfik Parmakizi Yöntemi’nin (RAPD-PCR) Türkiye yerli sığır ırklarında uygulanma olanakları" adlı doktora tezinden özetlenmiştir. (This paper has been summarized from the PhD dissertation of Güven GÜNEREN )
} 
reaction (PCR) using primers homologous to random target sites of genome $(20,24)$. The studies on population genetic structure and genetic variation using RAPD were claimed to be quite successful $(8,23)$. The main advantages of RAPD technique are that it is easier, less labour intensive, quicker and cheaper than the other DNA marker assays, and may also provide markers of choice for population studies, where a large number of individuals have been studied $(1,2,3)$. The RAPD-PCR method is used to determine relationships among different breeds and individuals and to formulate breeding strategies and also used to control the pedigree records of the animals $(5,22)$.

This study has the importance of being one of the first studies on native Turkish cattle breeds by using molecular techniques. The purpose of this study was to investigate the use of RAPD-PCR method in native cattle breeds of Turkey by estimating the genetic variation within and between the breeds. It is expected that the results of this study may have important implications for the protection, preservation and perpetuation of the native Turkish cattle breeds.

\section{Material and Method}

Animals: Blood sample used for DNA isolation was collected from 77 animals belonging to four native Turkish cattle breeds. Animals were sampled from their native breeding areas based on the phenotypic characteristics of each breed. The study was performed on 77 animals whose breeds, sex of animals and native breeding areas were shown in Table 1 .

DNA isolation and RAPD primers: Total DNA was extracted from peripheral blood sample using salting-out procedure (14). QIAamp ${ }^{\mathrm{TM}}$ blood kit was also used to isolate genomic DNA from blood sera of TG. Ten random primers (Biotech $^{\mathrm{TM}}$ GMBH, Germany) were used for DNA amplification. Each random primer was a 10 -mer with GC content varying from $50 \%$ to $80 \%$. Four primers (P01, P06, $\mathrm{P} 09$ and $\mathrm{P} 10)$ in females and three primers (P04, P08 and P10)in males were selected for further use in genotyping. The base sequence and length of the primers were shown in Table 2.

$R A P D-P C R$ analysis: RAPD-PCR was carried out on DNA from individual cattle as well as pooled DNA samples (mixture of individual DNA samples within the same breed) from each breed. Breed-specific genomic DNA samples were prepared by pooling the some amount of genomic DNA from each individual of the respected breed. RAPD-PCR amplifications of each animal were performed in $13.2 \mu \mathrm{l}$ reaction mixtures containing; $0.2 \mathrm{mM}$ of primer, $1.25 \mathrm{U} \mathrm{Taq}^{\mathrm{TM}}$ polymerase, $25 \mathrm{mM} \mathrm{MgCl}, 10 \mathrm{mM}$ dNTP and $200 \mathrm{ng}$ of genomic DNA. Amplifications were performed using a Techne ${ }^{\mathrm{TM}}$ thermal cycler that was programmed for 45 cycles of at $94^{\circ} \mathrm{C}$ for $1 \mathrm{~min}$, at $35^{\circ} \mathrm{C}$ for $30 \mathrm{sec}$ and at $72^{\circ} \mathrm{C}$ for $1 \mathrm{~min}$, and a final extension at $76^{\circ} \mathrm{C}$ for 6 min for elongation. RAPD-PCR amplifications of each animal were performed at least twice for confirmation of the accuracy and the repeatability of the products. Amplification products were separated by agarose gel (1.4\%) electrophoresis and detected by ethidium bromide staining.

DATA Analysis: Ten primers were screened and 6 of those were selected for further use as their large and distinct amplified bands (RAPD). The presence or absence of these RAPD bands was represented as either 1 or 0 respectively. The genetic variability within and between the populations were estimated based on the presence or absence of the bands within RAPD patterns. The RAPD Distance Package ${ }^{\mathrm{TM}}$ (Version 1.04) was utilized for the calculation of the distance matrix. This method was first developed by Excoffier et al. (11) and was used for the comparison among the animals. The

Table 1. The breeds, sex of animals and native breeding areas.

Tablo 1. Irklar, hayvanların cinsiyetleri ve örneklerin toplandığı bölgeler

\begin{tabular}{l|l|c|c|c}
\hline Breed & Areas & Male & Female & Total \\
\hline AB & Çubuk, Lalahan, Çorum, Çankırı & 7 & 9 & 16 \\
EAR & Elazı̆̆, Erzurum, Bingöl & 9 & 14 & 23 \\
SAR & Adana, Gaziantep, Kilis, Urfa & 15 & 4 & 19 \\
TG & Balıkesir, Çanakkale, Edirne, Kırklareli & 10 & 9 & 19 \\
\hline
\end{tabular}

Table 2. The base sequences and length of primers.

Tablo 2. Çalışmada kullanılan primerlerin baz dizileri ve uzunlukları

\begin{tabular}{c|l|c|l}
\hline Primer Name & Base Sequence & Primer Name & Base Sequence \\
\hline P01 & 5'-AGC TGT CTC A-3' & P06 & 5'-CTG CAG CCG T-3' \\
P02 & 5'-GCG TAT CTG T-3' & P07 & 5'-GAC AGG CGT C-5' \\
P03 & 5'-TGC CGG ATG A-3' & P08 & 5'-CGC TTG GCG G-3' \\
P04 & 5'-GGT CAC CTA C-3' & P09 & 5'-CCA GGA CGC G-3' \\
P05 & 5'-GGC TGC AGT G-3' & P10 & 5'-GCG CGC ACT C-3' \\
\hline
\end{tabular}


Similarity Matrix was also formed for each individual, and the dendrograms were built to observe genetically relations among individuals. The dendrograms were structured by the software Statistica ${ }^{\mathrm{TM}}$ (21). The significance of the variance components and F-statistics between and within the breeds were conducted through using a permutation approach called "Analysis of Molecular Variance" (AMOVA), eliminating the normality assumption (11). Estimates of the distances among breeds were carried out by $\mathrm{F}_{\mathrm{ST}}$ Distant Estimation Method, and cluster trees were constructed by UPGMA method. Arlequin 1.1 ${ }^{\mathrm{TM}}$ was used to calculate the genetic variation and variation analyses. The significance within and also between populations was tested by applying Fischer's " $2 \times 2$ random distribution table" (18). The method proposed by Reynolds et al. (17) was used for calculation of genetic distances between the breeds.

\section{Results}

In this study, initially ten random primers were tested to amplify individual and pooled DNA samples. Reproducible and distinct RAPD profiles in one or more breeds were generated through six out of the ten primers, whereas the other primers failed to produce polymorphic patterns. Based on the distinct band pattern, reproducibility, and the presence of diagnostic bands, four primers (P01, P06, P09 and P10) in females and three primers (P04, P06 and P10) in males were chosen for further analysis. From these primers, a total of 260 RAPD bands were obtained from the four cattle breeds. Amplified products ranged from $150 \mathrm{bp}$ to $950 \mathrm{bp}$ in size. In order to study the genetic relations among the four breeds, and to classify the RAPD data, the RAPD-PCR analysis was also run for the pooled DNA samples.

Primers exhibited informative patterns of amplified DNA fragments revealing within breed and between breeds differences. The RAPD bands obtained from the male DNA samples with PCR using three primers are shown in Figure 1. The RAPD bands produced from the female DNA samples using primer P10 are shown in Figure 2.

The maximum number of bands was obtained with the primers P01, P06, P09 and P10 in females; whereas, the primers P04, P08 and P10 yielded the maximum number of RAPD bands in males.

Within breed genetic variation: In the calculation of genotypic variation within breed according to the each primer and primer group in sex groups, in females it was found that the highest variation (0.809) was in SAR and the lowest variation (0.637) was in TG. The lowest genotypic variation was observed in $A B$ and $E A R$ (0.500) with primer P09 in females. In males, the highest genotypic variation was detected in TG (0.810) with primer P10, and the lowest genotypic variation was observed in SAR (0.105) with primer PO8.

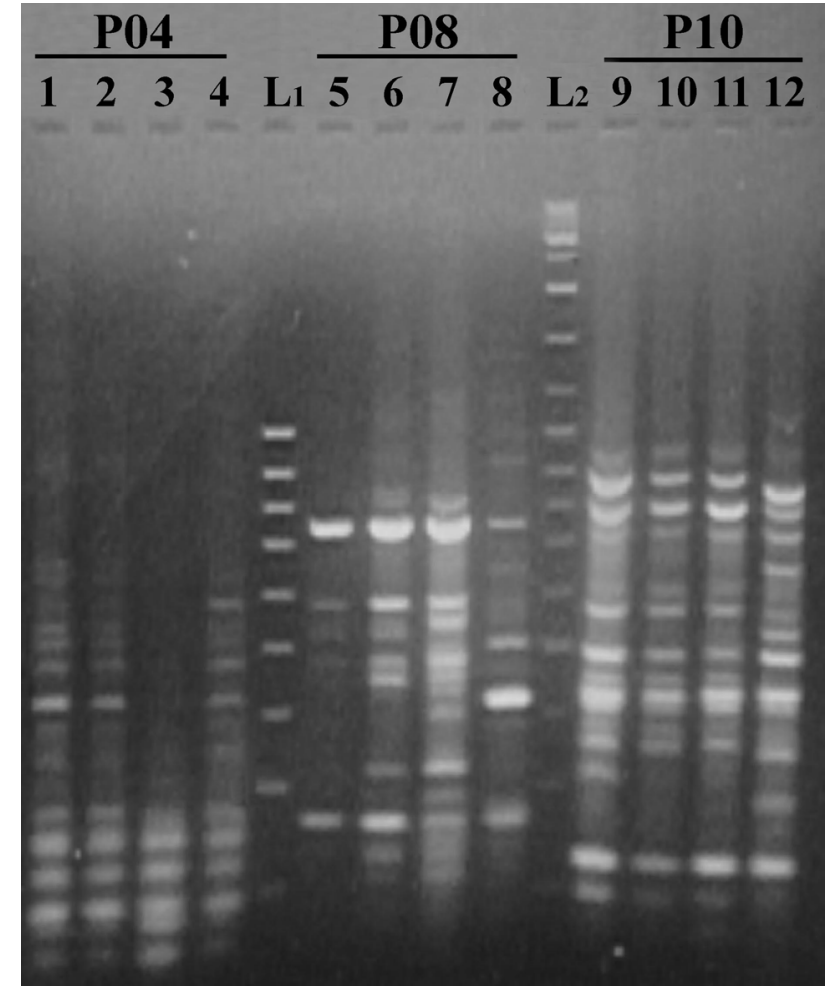

Figure 1: RAPD bands of P04, P08, P10 primers of some native Turkish male cattle including (Anatolian Black: 1, 5, 9; East Anatolian Red: 2, 6, 10; South Anatolian Red: 3, 7, 11; Turkish Gray: 4, 8, 12; L1: 100bp DNA ladder, L2: 1kb DNA ladder). Şekil 1: P4, P8 ve P10 primerleri ile yerli sı̆̆ır 1rklarının erkeklerine ait RAPD bantları (Yerli Kara: 1, 5, 9; Doğu Anadolu Kırmızısı: 3, 7, 10,; Boz Irk: 4, 8, 12, L1: 100 bp'lik DNA merdiveni, L2 : 1 kb'lik DNA merdiveni).

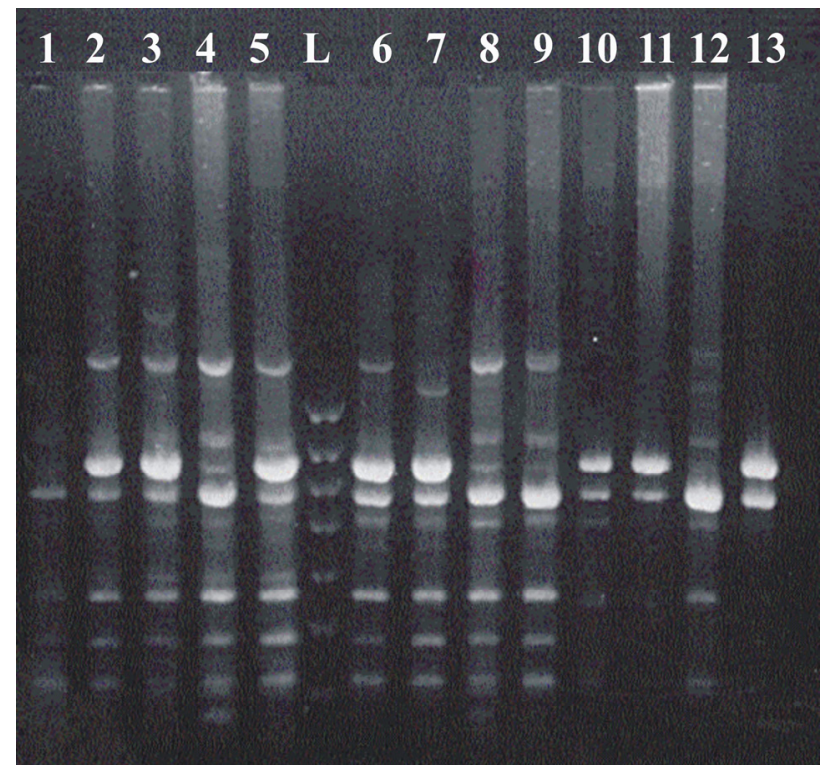

Figure 2: RAPD bands of P10 primer of some native Turkish female cattle (L: 100bp DNA ladder, no1: SAR female, no: 2-5 AB female, no: 6-11 EAR female, no: 12-13 SAR female).

Şekil 2: P10 primeri ile yerli sığır ırklarının dişilerine ait RAPD bantları (L 100bp'lik DNA merdiveni: no:1 GAK dişi, no2-5: Yerli Kara dişi, no 6-11: DAK dişi, no 12-13 :GAK dişi). 
Classification of Turkish native cattle breeds according to RAPD bands: In females the RAPD bands obtained with the primers P01, P06, P09 and P10 indicated that EAR and $\mathrm{AB}$ had the closest genetical distance. SAR was more distant from the cluster of EAR and $\mathrm{AB}$, while $\mathrm{TG}$ exhibited a distinct location from the other three breeds. Based on the RAPD bands obtained in males with primer P04, two groups were formed as SARTG and EAR-AB. Primer P08 also verified two groups as TG-AB and EAR-SAR. Primer P10 revealed SAR itself as a different group from the other breeds. The genetic distances among the breeds were calculated according to the RAPD bands obtained with primer P10 and the results are presented in Table 3. Cluster trees of native Turkish cattle breeds based on P10 primer are presented in Figure 3.

Table 3. Calculated genetic distances among the breeds according to the RAPD bands obtained with P10.

Tablo 3. P6 primeri ile elde RAPD bantlarına göre irklar arasındaki hesaplanan genetik mesafeler

\begin{tabular}{ccccc}
\hline Breed & AB & EAR & SAR & TG \\
\hline AB & 0.000 & & & \\
EAR & 0.088 & 0.000 & & \\
SAR & 0.325 & 0.115 & 0.000 & \\
TG & 0.286 & 0.213 & 0.396 & 0.000 \\
\hline
\end{tabular}

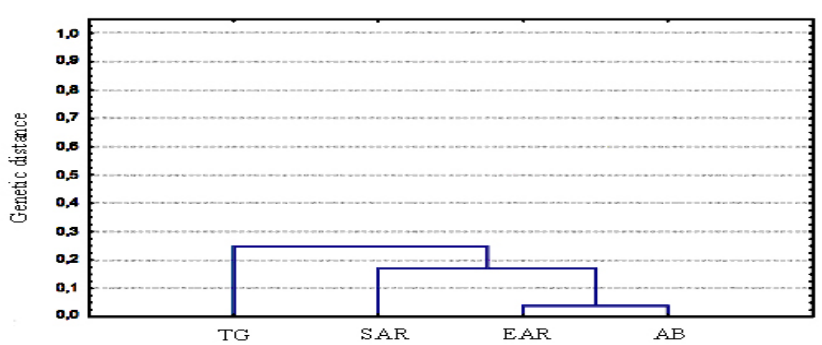

Figure 3. Cluster trees of breeds according to the RAPD bands with P10 primer.

Şekil 3: P6 primeri ile elde edilen RAPD bantları göre oluşturulan yerli sığır ırklarının ait kümeleme ağacı

\section{Discussion and Conclusion}

The aim of cattle breeding is to get a high efficiency and profit per animal, therefore, high efficiency breeds have been widely preferred and raised by farmers. Due to their low efficiencies, many local breeds around the world are now under the threat of extinction. This is also the case with the Turkish local cattle breeds, whose numbers have decreased almost by half over the last decade (7). Extinction of any local breed or population may result in complete loss of some valuable alleles or genetic variations which would affect the future genetic development. In spite of commercial value of Turkish local cattle breeds, except the information on the blood groups (10) and blood protein polymorphism (15), and traditional phenotypic characteristics, the population structure of these breeds are virtually unknown. The relation between the calculated genotypic variation and the sample size was found as non significant indicating that the number of animals in the groups was sufficient.

Although 10 bp primers have been widely used in many RAPD-PCR studies $(2,9,20,19)$, there are also reports using longer primers than $10 \mathrm{bp}$ primers in cattle $(1,3,5,13)$. The primers which generated lower number of RAPD bands were not included in the study considering that higher number of RAPD bands would yield more reliable information about the genotypes of populations. In fact, various numbers of primers were used in similar studies in different species $(3,12)$. For example, Li et al. (12), tried 100 primers but used only 16 in their studies. In this study, six primers capable of producing clear and reproducible bands were screened from 10 random primers for the amplification of total DNA of individuals.

In this study, some of the primers gave no bands in some samples. The reason may have either been in low quality DNA sample or the animal could be homozygote recessive for these loci. However, Apostol et al. (8) reported that such a case is practically impossible. In some cases, a particular primer pair may give band in one sex but not in the other. This might be interpreted as the primer is specific to one of the sex chromosomes. Some common bands in one breed may be specific to that breed, while some common bands in different breeds may be explicitly to a higher zoological rank. The proportion of primers capable of detecting polymorphism among the breeds was evaluated depending on the genetic background of breeds, genetic distance between the breeds and the complexity of genome (2). However, this and earlier studies $(1,3,12,24)$ indicated that RAPD analysis requires screening of a large number of random primers for detecting polymorphism.

Genetic markers with RAPD-PCR method are obtained with the identification of polymorphism based upon the existence of RAPD bands. Therefore, it is important to identify as many RAPD bands as possible. In a study on Holstein progeny test bulls, primers with 10 bp in length and $60-70 \% \mathrm{G}+\mathrm{C}$ content were used and produced 4-10 bands (6). In this study, ten bases in length and $50-80 \% \mathrm{G}+\mathrm{C}$ content were used, yielding 4 to 15 RAPD bands per primer.

The dendograms of these RAPD bands demonstrated that these bands were also observed on the level of individuals as well as among the individuals of the same breed. This finding may justify that the method could even be used for the studies of individuals.

The analyses of variance were made for the test of significance among the breeds with regarding to the location and the number of the RAPD bands. According to the observed RAPD bands obtained with the all 
primers in the sex groups, the differences among the breeds were found significant $(\mathrm{P}<0.05)$ justifying the idea that the primers could be used for the classification of the breeds. There was a similarity between the classifications of the phenotypic breed characteristics in the native cattle breeds of Turkey and that of the results of RAPD-PCR method. In addition to the phenotypic characteristics, it may be concluded that RAPD-PCR fingerprinting method could be used in classifications of breeds.

The studies with females, using primer P06 indicated that, EAR and $\mathrm{AB}$ were genetically the closest. The SAR was quite distant group from EAR and AB. The TG was as completely different group from the other three breeds.

In case of males, primer P08 was used and it was found that SAR-EAR and TG-AB breeds displayed some similarities. These breeds are also raised in neighbouring geographical areas. As to the classification of males with primer P10, it was observed that the genetic distance between SAR and EAR was the shortest, but the SAR formed a distant group from the other three breeds. According to RAPD analysis, AB showed the closest genetic distance with EAR and maximum genetic distance was found between $\mathrm{TG}$ and the other three breeds. These findings were in agreement with the report, R-S Blood Groups in cattle breeds of Turkey (10) and the haemoglobin allele frequency in cattle breeds of Turkey (15).

It may be inferred from the study that $\mathrm{TG}$ is a distant breed from the other three breeds, and the SAR had a different genetic structure from EAR and AB. These conclusions are in the line of "Microsatellite Analyses on 15 Middle East and European cattle breeds" by Loftus et al. (13). Another point is that TG is descendant of Bos taurus primigenius while the other three breeds rooted from Bos taurus brachiceros (4). However, further studies and confirmations may be needed to clarify the border lines of these local breeds.

The RAPD technique has also been used for constructing phylogenic relationships in different animals such as; goat (1), horse (1), cattle $(1,2,3,16)$, sheep (1, $3,9,12)$, dog (19), buffalo (1), swine (12) and chicken (2, 20, 24). Although the RAPD technique has low reproducibility (24), this and earlier studies showed that it is efficient technique because of its simplicity, speed and low cost $(2,20)$.

In conclusion, the results of this study indicated the effectiveness of RAPD markers in detecting the polymorphism and estimating genetic distance among Turkish native cattle breeds, and also the RAPD markers provide a potential tool for studying within breed and between breeds genetic variability and for establishing genetic relationships. Approaches employing several
DNA marker systems would increase the accuracy of genetic studies in local animal breeds and species.

\section{Acknowledgement}

The authors would like to thank to Prof. Dr. Orhan ALPAN and Ass Prof. Dr. Hilal OZDAG for his comments and critical reviewing of the manuscript.

\section{References}

1. Abdel-Rahman SM, Hafez EE (2007): Genetic similarity among the three Egyptian water buffalo flocks using RAPD-PCR and PCR-RFLP techniques, Res J Agric \& Biol Sci, 3, 351-355.

2. Ahlawat SPS, Sunder J, Kundu A, Chatterjee RN, Rai RB, Kumar B, Senani S, Saha SK, Yadav SP (2004): Use of RAPD-PCR for genetic analysis of Nicobari fowl of Andamans. Br Poult Sci, 45, 194-200.

3. Ali BA (2003): Genetics similarity among four breeds of sheep in Egypt detected by random amplified polymorphic DNA markers. Afr J Biotechnol, 2, 194-197.

4. Alpan O, Arpacik R (1996): Siğır Yetiş̧tiriciliği. Ankara, Şahin Matbaas1, pp.39-44.

5. Alves BCA, Unanian MM, Silva E, Oliveira M, Moreira-Filho CA (2005): Use of RAPD markers for identifying Nelore bulls with early reproductive maturation onset. Anim Reprod Sci, 85, 183-191.

6. Ambady S, Carpio CM, Ponce De León FA (1996): Optimization of RAPD-PCR conditions in cattle. Anim Biotechnol, 7, 99-122.

7. Anonym (2009): Türkiye İstatistik Kurumu. Erişim: http://www.tuik.gov.tr. Access Date: 15 May 2009.

8. Apostol BL, Black WC, Reiter P, Miller BR (1996): Population genetics with RAPD-PCR markers: the breeding structure of Aedes aegypti in Puerto Rico. Heredity, 76, 325-334.

9. Elmaci C, Oner Y, Ozis S, Tuncel E (2007): $R A P D$ analysis of DNA polymorphism in Turkish sheep breeds. Biochem Genet, 45, 691-696.

10. Ertugrul O, Alpan O, Dogrul F (1991): Blood group polymorphism in Turkish cattle breeds. Doğa-Tr J of Vet Anim Sci, 15, 328-337.

11. Excoffier L, Smouse P, Quattro J (1992): Analysis of molecular variance inferred from metric distances among DNA haplotypes: Application to human mitochondrial DNA restriction data. Genetics, 131, 479-491.

12. Li L, Zhang J, Zhu JJ, Gu S, Sun Q, Zhou GM, Fu CX, Li Q, Chen LY, Li DX, Liu SJ, Yang ZR (2006): Genetic diversity of nine populations of the Black Goat (Capra hircus) in Sichuan, PR China. Zoolog Sci, 23, 229234.

13. Loftus RT, Ertugrul O, Harba AH, El-Barody MAA, Machugh DE, Park SDE, Bradley DG (1999): $A$ microsatellite survey of cattle from a centre of origin: the Near East. Mol Ecol, 8, 2015-2022.

14. Miller SA, Dykes DD, Polesky HF (1988): A simple salting out procedure for extracting DNA from human nucleated cells. Nucleic Acids Res, 16, 1215.

15. Ozbeyaz C (1991): Türkiye yerli sı̆̆ır ırklarında hemoglobin polimorfizmi. Ankara Üniv Vet Fak Derg, 38, 53-59. 
16. Parejo JC, Padilla JA, Rabasco A, Sansinforiano ME, Trancón MM (2002): Population structure in the endangered Blanca Cacereña bovine breed demonstrated by RAPD analyses. Genes Genet Syst, 77, 51-58.

17. Reynolds J, Weir BS, Cockerham CC, (1983): Estimation for the coancestry coefficient: a basis for short term genetic distance. Genetics, 105, 767-779.

18. Schneider S, Kueffer JM, Roessli D, Excoffier L (1997): Arlequin: A software for population genetic data analysis, version 1.1. Genetics and Biometry Lab, Dept. of Anthropology, Univ Geneva.

19. Semyenova SK, Illarionova NA, Vasil'ev VA, Shubkina AV, Ryskov AP (2002): Genetic analysis and estimation of genetic diversity in East-European breeds of windhounds (Canis familiaris L.) based on the data of genomic studies using RAPD markers. Genetika, 38, 704713.

20. Singh RV, Sharma D (2002): Within-and between-strain genetic variability in White Leghorn population detected through RAPD markers. Br Poult Sci, 43, 33-37.

21. Sneath PH, Sokal RR (1973): Taxonomy structure. In numerical taxonomy. The Principle and Practice of Numerical Classification. Ed. Kennedy D and Park RB pp.134-230. San Francisco, CA: Freeman.
22. Talle SB, Chenyabuga WS, Fimland E, Syrstad O, Meuwissen T, Klungland $\mathbf{H}$ (2005): Use of DNA technologies for the conservation of animal genetic resources: A review. Acta Agr Scand A-An, 55, 1-8.

23. Yu Y, Lian LS, Wen JK, Shi XW, Zhu FX, Nie L, Zhang YP (2004): Genetic diversity and relationship of Yunnan native cattle breeds and introduced beef cattle breeds. Biochem Genet, 42, 1-9.

24. Zhang X, Leung FC, Chan DKO, Yang G, Wu C (2002b): Genetic diversity of Chinese native chicken breeds based on protein polymorphism, randomly amplified polymorphic DNA, and microsatellite polymorphism. Poult Sci, 81, 1463-1472.

Geliş tarihi: 20.04.2009 / Kabul tarihi: 22.10.2009

\section{Yazışma adresi:}

Prof. Dr. Okan Ertuğrul

Ankara Üniversitesi Veteriner Fakültesi

Genetik Anabilim Dall,

Dışkapı / Ankara.

Email:ertugrul@veterinary.ankara.edu.tr 